\title{
Klasifikasi Jenis Kayu Menggunakan Esktrasi Fitur Gray Level Co-Occurence Matrix dan Multilayer Perceptron
}

\author{
Deni Wahyu Wibowo*, Danang Erwanto dan Diah Arie Widhining Kusumastutie \\ Program Studi Teknik Elektro, Fakultas Teknik, Universitas Islam Kadiri \\ ${ }^{*}$ Corresponding author, e-mail: deniwahyuww@gmail.com
}

\begin{abstract}
Abstrak - Jenis kayu umumnya dicirikan dari warna, corak dan serat karena kayu secara fisik memiliki ciri yang hampir sama. Untuk menentukan jenis kayu, diperlukan pengalaman dan pengetahuan tentang kayu. Penelitian ini menerapkan teknologi pengolahan citra digital menggunakan metode ekstraksi fitur GLCM (gray level co-occourrence matrix) untuk menghasilkan nilai ekstraksi fitur pada tesktur kayu. Parameter nilai dihasilkan pada ekstraksi fitur GLCM adalah correlation, contrast, energy dan homogeneity. Hasil dari parameter GLCM kemudian digunakan sebagai data untuk klasifikasi jenis kayu menggunakan metode MLP (multilayer perceptron). Dalam penelitian ini digunakan 4 jenis kayu sebagai pengujian dan datasheet, yaitu kayu jati, sengon, mahoni dan mindi. Hasil dari penelitian ini, diperoleh tingkat akurasi terbaik pada data validasi sebesar $88,75 \%$. Keluaran dari penelitian ini berupa data softmax dengan menggunakan metode MLP dengan nilai error pada data training yang mendekati target sebesar 0.029421 dengan epoch 1.000 iterasi.
\end{abstract}

Kata Kunci : Pengolahan Citra Digital, Ekstraksi Fitur, GLCM dan MLP

\begin{abstract}
The type of wood is generally characterized by color, pattern and fiber because wood physically has almost the same characteristics. To determine the type of wood, experience and knowledge about wood are needed. This study applies digital image processing technology using the GLCM (gray level cooccurrence matrix) feature extraction method to produce feature extraction values on wood texture. The parameter values generated in the GLCM feature extraction are correlation, contrast, energy and homogeneity. The results from feature extraction are then used as a data classification of types of wood using MLP (multilayer perceptron) method. There are 4 wood types going to be involved in this research as datasets i.e., teak, sengon, mahogany, and mindi. The results of this study, obtained the best level of accuracy in validation data of $88.75 \%$. The output of this research is softmax data using MLP method with an error value in the training neared target of data by 0.029421 with the epoch 1.000 iterations.
\end{abstract}

Keywords : Digital Image Processing, Feature Extraction, GLCM and MLP

\section{Pendahuluan}

Pengidentifikasian jenis kayu pada umumnya dicirikan berdasarkan ukuran, warna, serat dan corak. Pengenalan atau pengidentifikasian jenis kayu tersebut umunya masih secara manual dengan melakukan pengamatan secara visualisasi berdasarkan ciri dari kayu tersebut.

Dalam proses pengidentifikasian jenis kayu secara manual sering terjadi kesalahan, karena kurangnya pengalaman dan pengetahuan tentang kayu. Selain itu jika dilihat secara langsung, kayu memiliki corak atau bentuk tekstur yang hampir sama sehingga waktu yang dibutuhkan untuk mengidentifikasi jenis kayu tersebut membutuhkan proses yang cukup lama, karena perlu dilakukan secara berulang-ulang dan terus-menerus untuk memastikan kebenaran jenis kayu tersebut.

Salah satu teknik untuk melakukan pengenalan citra yang secara signifikan tidak dapat dikenali oleh mata antara lain dengan membedakan teksturnya. Tekstur dalam citra digital merupakan suatu komponen dasar dalam membentuk citra digital. Tekstur dari citra digital dapat dibedakan melalui kerapatan, keseragaman, keteraturan, kekasaran, dan lain-lain [1]. Sebuah citra RGB (Red, Green, Blue) memiliki unsur warna merah, warna hijau dan warna biru. Sedangkan pada citra skala keabuan (grayscale) memiliki unsur-unsur entropy, inertia, energy, dan correlation. Ketujuh unsur ini dapat dijadikan masukan ke sistem komputer untuk diolah lebih lanjut dalam pengenalan jenis kayu [2]. Penelitian mengenai ekstraksi fitur dari tekstur 
kayu dengan mengkombinasikan Gray Level CoOccourrence Matrix (GLCM) dan pendeteksian tepi dilakukan untuk mendapatkan karakteristik tekstur kayu [3]. Pengklasifikasian kualitas jenis kayu jati berdasarkan teksturnya dengan menggunakan metode GLCM dan Jaringan Syaraf Tiruan backpropagation pernah dilakukan untuk membantu sistem melakukan pengenalan pola tekstur serat dari kayu jati dengan mengambil nilai parameter korelasi, kontras, homogenitas dan energi [4].

Penelitian ini melakukan pengklasifikasian jenis kayu jati, sengon, mahoni dan mindi berdasarkan tekstur kayu dengan mengimplementasikan pengolahan citra digital menggunakan ekstraksi fitur tekstur GLCM dan algoritma Multilayer Perceptron (MLP) dengan tujuan menghasilkan nilai parameter ekstraksi ciri GLCM sebagai input MLP untuk mengidentifikasi jenis kayu. Metode GLCM sendiri merupakan metode yang mampu menyediakan informasi yang penting mengenai tekstur citra [5]. Informasi tekstur citra ini digunakan sebagai data masukan pada proses pengklasifikasian jenis kayu menggunakan algoritma MLP. MLP merupakan metode pembelajaran mesin (Machine Learning) yang mempresentasikan prinsip kerja yang hampir menyerupai system saraf pada manusia.

\section{Metode}

Jenis kayu biasanya ditentukan berdasarkan ukuran, warna, corak dan tekstur dari kayu itu sendiri. Setiap jenis kayu memiliki sifat fisik yang beragam. Penelitian ini merancang system yang digunakan untuk mengklasifikasikan jenis kayu jati, sengon, mahoni dan mindi berdasarkan tekstur yang dimiliki oleh masing-masing jenis kayu.

Kayu memiliki sifat istimewa, karena tidak dapat ditiru oleh bahan-bahan lain [6]. Secara umum jenis kayu dengan dibagi menjadi dua antara lain kayu daun jarum (softwood) atau biasa dikenal dengan conifer dan kayu daun lebar (hardwood) yang biasa disebut dengan angiosperm [7].

Pada penelitian ini data yang digunakan dibagi menjadi dua jenis data yaitu citra data latih dan citra data uji. Data tersebut memiliki jumlah sebanyak 400 data dengan masing-masing 100 data dari setiap jenis kayu yang diteliti dengan proporsi citra sebesar $320 \times 240$ pixel. Citra data latih pada penelitian ini digunakan sebagai setting point atau training pada proses pengklasifikasian program. sedangkan untuk pengujian jenis kayu pada penelitian ini jumah citra data testing sebanyak 80 data dengan masing-masing jenis kayu menggunakan 20 data perjenis kayu untuk keperluan akurasi. Data uji digunakan untuk testing program. Penentuan proporsi data untuk keperluan training dan validasi dilakukan secara acak atau random.

Tabel 1. Parameter data masukan

\begin{tabular}{|l|c|c|}
\hline & $\begin{array}{c}\text { Citra Data } \\
\text { Training }\end{array}$ & $\begin{array}{c}\text { Citra Data } \\
\text { Testing }\end{array}$ \\
\hline $\begin{array}{l}\text { Jumlah Data } \\
\text { (citra) }\end{array}$ & 400 & 80 \\
\hline $\begin{array}{l}\text { Resolusi } \\
\text { (Piksel) }\end{array}$ & $320 \times 240$ & $320 \times 240$ \\
\hline Ruang Warna & Grayscale & Grayscale \\
\hline
\end{tabular}

Citra tekstur kayu yang digunakan sebagai datasheet dan data validasi seperti ditunjukkan oleh gambar 1 sebagai berikut.

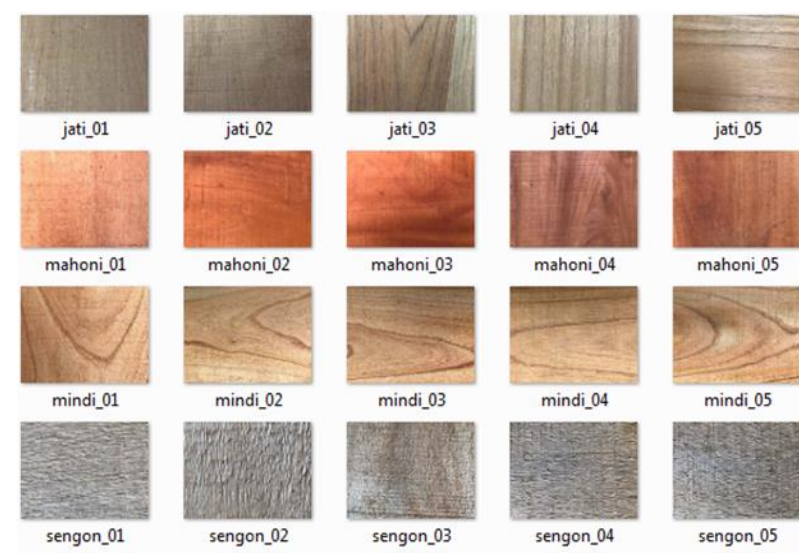

Gambar 1. Citra tekstur kayu yang digunakan sebagai datasheet dan data validasi

Pengambilan citra data latih menggunakan kamera ponsel yang memiliki resolusi kamera sebesar 12 Megapixel. Citra data latih mempunyai nilai piksel 255,0 piksel dari setiap data latih, nilai 255,0 piksel diperoleh dari proses resize citra asli dengan ukuran $320 \times 240$. Penamaan file dari citra data latih diseragamkan dengan format "jeniskayu_xx", dimana xx adalah nomor urut dari file citra data latih untuk mempermudah dalam proses checking jika terjadi error atau kendala lainnya. 


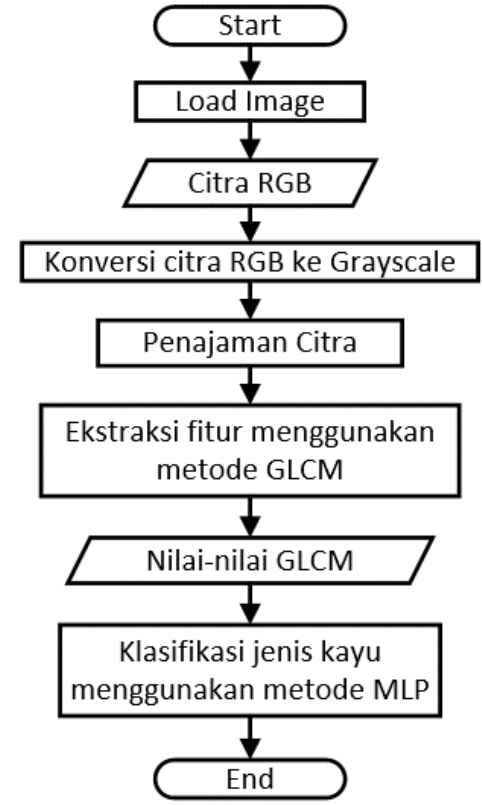

Gambar 2. Diagram alir system secara umum

Pengolahan citra digital digunakan untuk melakukan rekayasa dengan menggunakan komputer terhadap gambar 2 dimensi. Dalam konteks yang lebih luas, pengolahan citra digital mengacu pada pengolahan setiap data dari gambar 2 dimensi. Teknik yang dilakukan dalam pengolahan citra digital adalah melakukan manipulasi nilai pada masing-masing piksel. Citra digital merupakan sebuah larik (array) yang berisi nilai-nilai real maupun kompleks yang direpresentasikan dengan deretan bit tertentu [8]. Gambaran mengenai koordinat citra digital ditunjukkan oleh gambar 1.

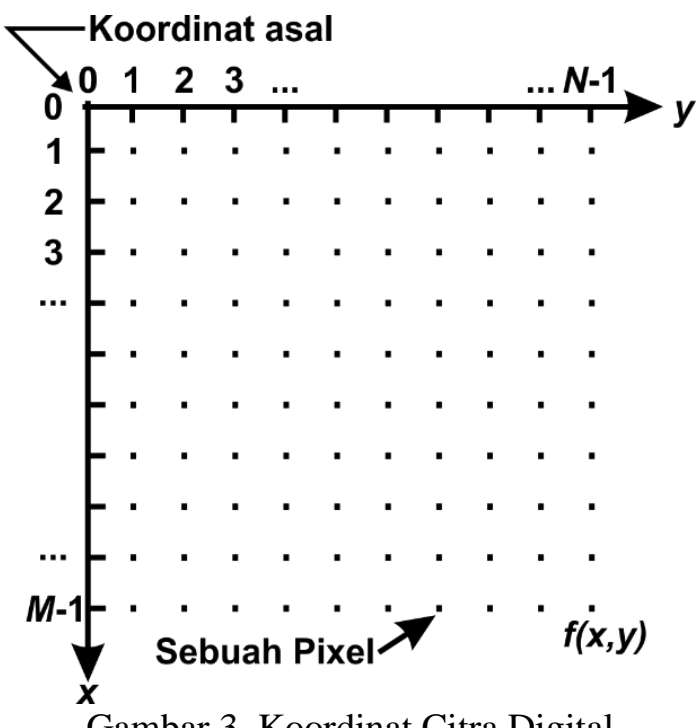

Gambar 3. Koordinat Citra Digital
Citra digital juga memiliki kanal warna dasar yang membentuknya yang terdiri dari merah, hijau dan biru sehingga dikenal dengan citra RGB [9]. Bentuk persamaan matrik dari citra digital ditulis seperti pada persamaan 1 sebagai berikut [8]:

$$
f(x, y)=\left[\begin{array}{cccc}
f(0,0) & f(0,1) & \ldots & f(0, N-1) \\
f(1,0) & f(1,1) & \cdots & f(1, N-1) \\
\vdots & \vdots & & \vdots \\
f(M-1,0) & f(M-1,1) & \cdots & f(M-1, N-1)
\end{array}\right]
$$

\subsection{Konversi Citra RGB ke Grayscale}

GLCM mengekstraksi fitur dari citra grayscale saja. Sehingga diperlukan konversi citra RGB ke grayscale dengan megubah nilai kanal warna $(r, g$ dan $b$ ) pada masing-masing piksel suatu citra menjadi nilai citra grayscale dengan nilai $s$. Proses konversi citra RGB menjadi citra grayscale adalah mengambil nilai rata-rata $r$, g, dan $b$ sehingga persamaannya dapat dituliskan seperti pada persamaan 2.

$s=\frac{r+g+b}{3}$

\subsection{Penajaman Citra}

Dalam pengolahan citra digital, penajaman citra atau image enhancement digunakan untuk memperjelas tepi pada obyek didalam suatu citra digital. Proses yang dilakukan dalam penajaman citra adalah dengan mempertegas citra pada frekuensi tinggi (high-pass filter). Dengan melakukan penajaman citra menggunakan metode high-pass filter didapatkan citra yang memberikan kesan dari garis pola tekstur kayu lebih tegas dan selanjutnya dilakukan ekstraksi fitur menggunakan metode GLCM. Proses penajaman citra pada penelitian ini lebih berfokus pada tekstur kayu agar mendapatkan tingkat akurasi yang lebih baik dalam proses pengklasifikasiannya.

Proses penajaman pada peneliti ini menggunakan nilai parameter r10a2 (radius 10 amount 2) dan r5a1(radius 5 amount 2), kemudian dibandingkan hasil pengolahan citra tersebut apakah memiliki pengaruh yang signifikan atau tidak dengan hasil keluarannya. Amount merupakan nilai kontras yang diaplikasikan pada kontur suatu citra di sekeliling citra objek yang akan ditajamkan. Jika nilai amount semakin besar maka efek penajamannya semakin tegas. Radius merupakan lebar kontur suatu sisi citra objek yang akan ditajamkan, jika nilai radius semakin besar maka sisi citra objek yang ditajamkan juga semakin lebar. 
Jika nilai dari radius terlalu besar maka akan memunculkan efek halo yang mengganggu.

\subsection{GLCM}

GLCM merupakan suatu matriks kookurensi yang menyajikan hubungan ketetanggaan antarpiksel dalam citra dari berbagai arah orientasi dan jarak spasial. Seperti ditunjukkan oleh gambar 4 , terdapat 4 sudut komputasi dalam GLCM, yaitu $\delta=0^{\circ}, \delta=45^{\circ}, \delta=90^{\circ}, \delta=135^{\circ}$ [10] yang menetukan arah hubungan ketetanggaan.

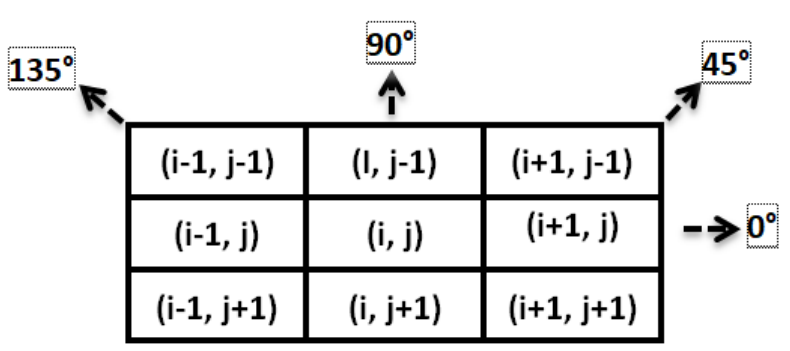

Gambar 4. Sudut Matrik Kookurensi

GLCM dihasilkan dengan menghitung nilainilai intensitas tingkat abu-abu yang ditemukan bersama dalam suatu gambar yang diberikan hubungan spasial linier antara dua piksel [11]. Fitur GLCM yang digunakan dalam penelitian adalah contrast, correlation, energy, homogeneity dan entropy.

\subsubsection{Kontras (contrast)}

Kontras merupakan suatu nilai intensitas aras keabuan antara piksel satu dengan piksel yang lainnya dengan lokasi relatif. Batas nilai dari kontras adalah 0 hingga pangkat 2 dari panjang suatu matrik GLCM simetris. Pada citra dengan elemen piksel yang memiliki nilai sama secara keseluruhan, maka nilai kontras adalah 0. Untuk mendapatkan ekstraksi fitur kontras digunakan persamaan 3 [12].

$$
\text { Cont }=\sum_{d} \sum_{y}(d-y)^{2} p(d, y)
$$

Dalam perhitungan kontras, nilai $p$ menunjukkan nilai piksel (amplitudo) dalam GLCM, sedangkan $d$ merupakan indeks untuk elemen lateral (jejak $d$ ) dan $y$ menunjukkan indeks untuk elemen vertikal (waktu $y$ ).

\subsubsection{Korelasi (correlation)}

Korelasi pada metode GLCM digunakan untuk mengukur keterkaitan linier dari aras keabuan pada suatu ketetanggaan piksel citra. Nilai ekstraksi fitur korelasi diperoleh menggunakan persamaan 4 .

Corr $=\sum_{d} \sum_{y} \frac{(d-\mu d)(y-\mu y) p(d, y)}{\sigma d \sigma y}$

Dengan :

$\mu d=\sum_{d} \sum_{y} d p_{(d, y)}$
$\mu y=\sum_{d} \sum_{y} y p_{(d, y)}$

Dan varian GLCM adalah:

$\sigma d=\sqrt{\sum_{d} \sum_{y}(d-\mu d)^{2} p_{(d, y)}}$

$\sigma y=\sqrt{\sum_{d} \sum_{y}(y-\mu y)^{2} p_{(d, y)}}$

\subsubsection{ASM (Angular Second Moment)/Energy}

ASM merupakan penjumlahan pangkat dari elemen matrik GLCM. Nilai ASM akan tinggi ketika citra memiliki nilai homogenitas yang baik atau memiliki nilai piksel yang hampir serupa. Persamaan 9 digunakan untuk mencari ekstraksi fitur dari ASM.

$$
E n g=\sum_{d} \sum_{y} p(d, y)^{2}
$$

\subsubsection{Homogeneity}

IDM (Inverse Difference Moment) atau biasa disebut dengan homogeneity/homogenitas lokal. IDM merupakan kebalikan dari bobot kontras dimana IDM akan bernilai besar jika saat ASM yang memiliki nilai tetap mempunyai nilai pixel yang sama. Persamaan 10 digunakan untuk mendapatkan nilai dari ekstraksi fitur IDM.

$H o m=\sum_{d} \sum_{y} \frac{p(d, y)}{1+|d-y|}$ 
Pada penelitian ini vektor contras, correlation, energy, dan homogeneity digunakan untuk mengintepretasikan tekstur citra. Pada dasarnya setiap fitur memiliki fungsi yang berbeda-beda tergantung pada penggunaanya.

\subsection{MLP (Multilayer Perceptron)}

Jaringan Saraf Tiruan (JST) adalah suatu model pengolahan informasi yang terinspirasi dari sistem sel syaraf biologi dan layaknya seperti otak yang mengolah suatu informasi. JST bersifat intensif komputasi dan intensif memori, membuatnya sulit untuk digunakan pada sistem tertanam/Embedded System [13]. MLP merupakan topologi paling umum dari JST. MLP banyak digunakan dalam berbagai aplikasi klasifikasi dan regresi dalam berbagai bidang pengenalan suara, pola dan masalah klasifikasi lainnya. Pada MLP perceptronperceptron terhubung membentuk beberapa lapisan (layer). Sebuah MLP mempunyai lapisan masukan (input layer), minimal satu lapisan tersembunyi (hidden layer), dan lapisan luaran (output layer) [14].

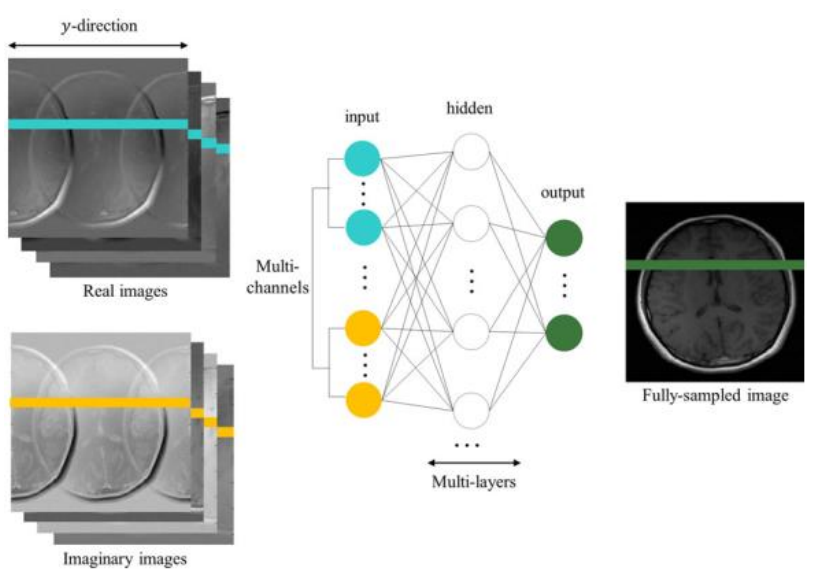

Gambar 5. Arsitektur MLP [15]

Setelah proses ekstraksi menggunakan metode GLCM maka nilai vektor yang dihasilkan diberikan label bilangan sesuai dengan klasfikasi yang telah ditentukan. Pada setiap data training jenis kayu memiliki jumlah 100 data per jenis kayu yang akan diklasifikasi.

Pada penelitian ini menggunakan 3 lapisan hidden layer dengan model arsitektur metode MLP seperti gambar 5. Jumlah neuron pada hidden layer pertama sebanyak 20 neuron, jumlah neuron hidden layer kedua 30 neuron, dan jumlah neuron hidden layer ketiga sebanyak 4 neuron dengan jumlah epoch yang akan digunakan sebesar 1.000 kali. Dalam penelitian ini menggunakan fungsi aktivasi jenis tansig (fungsi sigmoid bipolar) yang dijadikan data output dari pengolahan algoritma MLP.

Error keluaran output layer dihitung dengan cara mencari selisihnya nilai target yang ada dalam data training dengan nilai output dari neuron pada output layer seperti pada persamaan 11 berikut.

$E_{k}=t_{k}-y_{k}$

Dimana $E_{k}$ merupakan nilai error, $t$ adalah nilai target pada data training dan $y$ merupakan nilai output dari neuron pada output layer $\left(y_{k}\right)$. Jika output layer terdiri dari beberapa neuron maka error dihitung pada setiap neuron. Sedangkan faktor koreksi pada output layer $\left(\delta_{k}\right)$, dihitung menggunakan persamaan 12 sebagai berikut.

$\delta_{k}=E_{k} \cdot \delta_{k} \cdot Z_{j}$

Dimana $Z_{j}$ adalah hidden layer. Jika output layer terdiri dari beberapa neuron maka error dihitung pada setiap neuron. Untuk faktor perubahan bobot diantara output layer dan hidden layer $\left(\Delta v_{j k}\right)$ dapat dicari engan menggunakan persamaan 13 sebagai berikut.

$\Delta v_{j k}=\alpha \cdot y_{k}\left(1-y_{k}\right)$

Dimana $\alpha$ merupakan learning rate/laju pdengan rentang $0-1$. Sehingga faktor koreksi pada hidden layer $\left(\delta_{k}\right)$ dihitung menggunakaan persamaan 14 dan 15 sebagai berikut.

$\delta_{j}=\delta_{-} n e t_{\mathrm{j}} . Z_{\mathrm{j}}\left(1-Z_{j}\right)$

Dimana,

$\delta_{-} n e t_{\mathrm{j}}=\sum_{K=1}^{M} \delta_{k} \cdot V_{j k}$

Dalam klasifikasi jenis neural network biasanya menggunakan parameter MSE (Mean Squared Error) dan akurasi untuk evaluasi training. MSE sendiri merupakan parameter untuk mengevaluasi data training. Nilai MSE merupakan kuadrat dari jumlah selisih antara target $(t)$ dengan nilai output layer $\left(y_{k}\right)$ pada setiap iterasi/pengulangan $(i)$ dibagi dengan jumlah iterasi maksimumnya $(n)$ sebagaimana ditunjukkan oleh persamaan 16. 
$M S E=\frac{\sum\left(t_{i}-y_{k i}\right)^{2}}{n}$

Data keluaran yang dihasilkan dari algoritma MLP berupa nilai prediksi dan nilai data softmax hasil klasifikasi yang menampikan hasil dari nilai tertinggi yang didapat dari nilai prediksi. Nilai yang memiliki angka tertinggi dari hasil kemungkinan merupakan hasil dari pengklasifikasian tersebut. Data softmax dari pengolahan MLP menghasilkan nilai pada setiap jenis kayu kemudian dari hasil output tersebut dicari nilai tertinggi daripada hasil output yang lain. Dari data softmax tersebut menghasilkan satu jenis klasfikasi yang ditampikan dari empat jenis kayu yang diteliti, keluaran akhir pada penelitian ini adalah keterangan jenis kayu.

Persentase akurasi dapat dihitung dengan cara membagi jumlah prediksi benar $\left(y_{b}\right)$ dengan total data training $(m)$ dan dikalikan dengan 100\% sebagaimana disajikan oleh persaman 16.

Accuracy $=\frac{\sum y_{b}}{m} \times 100 \%$

\section{Hasil dan Pembahasan}

Analisis data penelitian ini menjelaskan hasil dari pengolahan citra dengan metode GLCM dan MLP mulai pembentukan datasheet, mengonversi citra input, pengolahan ektrasi GLCM, hasil prediksi dari pengolahan klasifikasi MLP sampai hasil klasifikasi berupada data softmax. Gambar 6 adalah tampilan antarmuka sistem untuk klasifikasi jenis kayu menggunakan metode GLCM dan MLP.

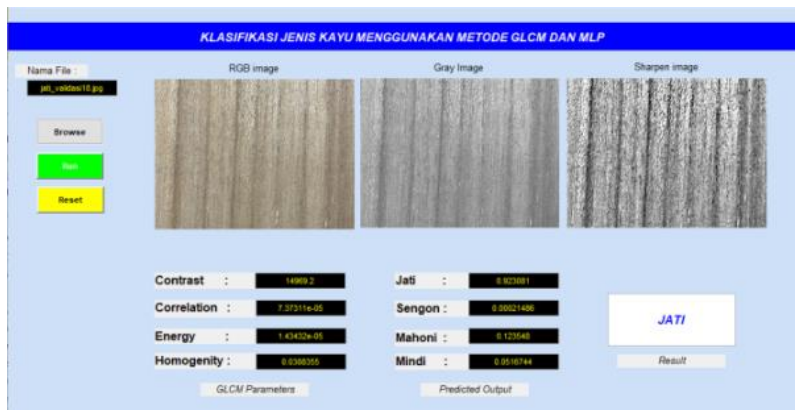

Gambar 6. Tampilan Interface GUI

\subsection{Penajaman Citra}

Citra input pada penelitian ini berupa citra RGB yang diubah ke citra grayscale, dan kemudian ditajamkan dengan proses penajaman citra dengan menggunakan 2 pilihan dalam penerapan nilai parameter, yaitu dengan parameter nilai radius 5 dan amount 1 dan parameter kedua dengan nilai radius 10 dan amount 2 dengan hasil uji coba seperti gambar 7 .

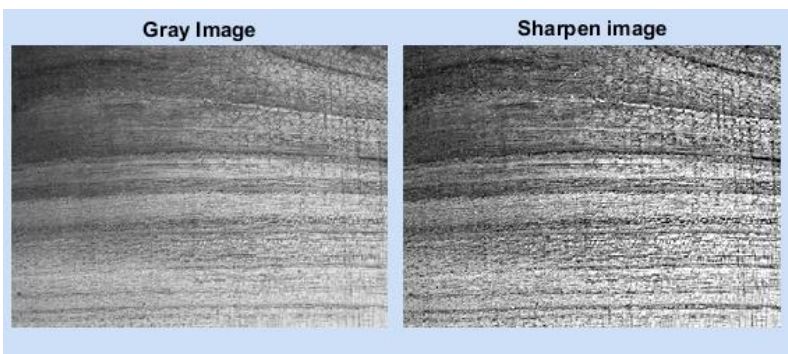

Gambar 7. Hasil Unmask pada Radius 5, Amount 1

Dengan perbandingan parameter sebesar 1:2, maka pada penerapan parameter kedua digunakan nilai radius 10 dan amount 2, sehingga didapatkan hasil seperti gambar 8 .

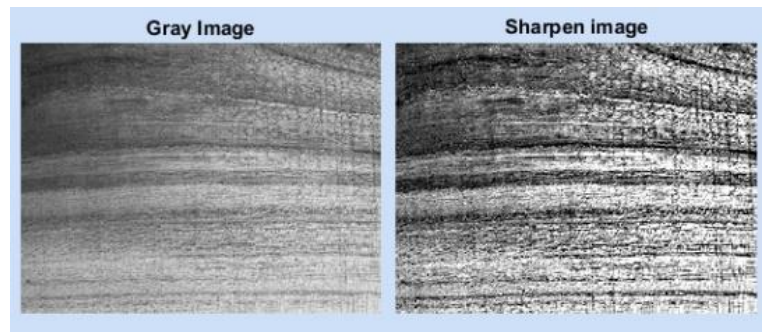

Gambar 8. Hasil unmask pada Radius 10, Amount 2

Pada penelitian ini digunakan nilai parameter untuk penajaman citra dengan radius 10 dan amount 2 karena pada parameter tersebut menghasilkan citra serat kayu yang lebih presisi dan terlihat lebih jelas citra tekstur kayunya dibandingkan dengan parameter sebelumnya.

\subsection{Esktrasi Fitur GLCM}

Gambar 9a, 10a dan 11a merupakan matrik awal yang dibentuk dari citra grayscale kemudian dilakukan kuantitasi menjadi 4 level skala keabuan $(0-3)$. Pembuatan matrik ketetanggaan (Gambar $9 \mathrm{~b}, 10 \mathrm{~b}$ dan 11b) berdasarkan matrik awal dengan menggunakan orientasi sudut $(\theta) 0^{\circ}$ dan jarak $(d)$ sebesar 1 piksel.

Korelasi antar piksel dengan sudut ketetanggaan $0^{\circ}$ didapatkan pada piksel pada koodinat $(0,0)$ dengan piksel pada koordinat $(0,1)$ dan pasangan ketetanggaan koordinat $(0,1)$ pada matriks framework bertambah 1 ditunjukkan oleh gambar matriks ketetanggaan sebagai berikut. 


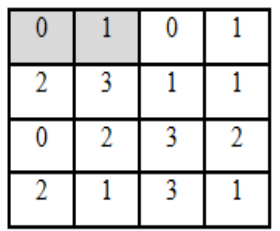

(a)

\begin{tabular}{|l|l|l|l|l|}
\cline { 2 - 5 } \multicolumn{1}{c|}{} & 0 & 1 & 2 & 3 \\
\hline 0 & 0 & 1 & 0 & 0 \\
\hline 1 & 0 & 0 & 0 & 0 \\
\hline 2 & 0 & 0 & 0 & 0 \\
\hline 3 & 0 & 0 & 0 & 0 \\
\hline
\end{tabular}

(b)
Gambar 9. a. matrik awal, b. Matriks

Ketetanggaan Piksel koordinat $(0,1)$ Bertambah 1

Korelasi antar piksel dengan sudut ketetanggaan $0^{\circ}$ yaitu pada piksel koordinat $(0,1)$ dengan piksel koordinat $(0,2)$. Pasangan ketetanggaan koordinat $(1,0)$ pada matriks framework GLCM bertambah 1 ditunjukkan oleh gambar matriks ketetanggaan sebagai berikut.

\begin{tabular}{|l|l|l|l|}
\hline 0 & 1 & 0 & 1 \\
\hline 2 & 3 & 1 & 1 \\
\hline 0 & 2 & 3 & 2 \\
\hline 2 & 1 & 3 & 1 \\
\hline
\end{tabular}

(a)

\begin{tabular}{|l|l|l|l|l|}
\cline { 2 - 5 } \multicolumn{1}{c|}{} & 0 & 1 & 2 & 3 \\
\hline 0 & 0 & 1 & 0 & 0 \\
\hline 1 & 1 & 0 & 0 & 0 \\
\hline 2 & 0 & 0 & 0 & 0 \\
\hline 3 & 0 & 0 & 0 & 0 \\
\hline
\end{tabular}

(b)
Gambar 10. a. matrik awal, b. Matriks

Ketetanggaan Piksel koordinat $(1,0)$

Bertambah 1

Korelasi antar piksel dengan sudut ketetanggaan $0^{\circ}$ yaitu pada piksel koordinat $(0,2)$ dengan piksel koordinat $(0,3)$. Pasangan ketetanggaan kordinat $(1,0)$ pada matriks framework GLCM bertambah 1 sehingga menjadi 2 ditunjukkan oleh gambar matriks ketetanggaan sebagai berikut.

\begin{tabular}{|l|l|l|l|}
\hline 0 & 1 & 0 & 1 \\
\hline 2 & 3 & 1 & 1 \\
\hline 0 & 2 & 3 & 2 \\
\hline 2 & 1 & 3 & 1 \\
\hline
\end{tabular}

(a)

\begin{tabular}{|l|l|l|l|l|}
\cline { 2 - 5 } \multicolumn{1}{c|}{} & 0 & 1 & 2 & 3 \\
\hline 0 & 0 & 2 & 0 & 0 \\
\hline 1 & 1 & 0 & 0 & 0 \\
\hline 2 & 0 & 0 & 0 & 0 \\
\hline 3 & 0 & 0 & 0 & 0 \\
\hline
\end{tabular}

(b)
Gambar 11. a. matrik awal, b. Matriks

Ketetanggaan Piksel koordinat $(0,1)$ Bertambah menjadi 2
Demikian proses tersebut berulang hingga baris ke-4 sehingga diperoleh matriks GLCM pada sudut $0^{\circ}$ seperti gambar 12 sebagai berikut.

\begin{tabular}{|c|c|c|c|c|}
\cline { 2 - 5 } \multicolumn{1}{c|}{} & 0 & 1 & 2 & 3 \\
\hline 0 & 0 & 2 & 1 & 0 \\
\hline 1 & 1 & 1 & 0 & 1 \\
\hline 2 & 0 & 1 & 0 & 2 \\
\hline 3 & 0 & 2 & 1 & 0 \\
\hline
\end{tabular}

\section{Gambar 12. Matriks $4 \times 4$ Dengan Sudut $0^{\circ}$}

Penjumlahan matriks GLCM seperti yang ditunjukkan oleh gambar 13 yaitu menggunakan transpose dari matriks itu sendiri sehingga menghasilkan matriks simetris. Kemudian matriks GLCM simetris tersebut dinormalisasi sehingga dapat dianalisis dengan menghitung masingmasing ekstraksi fiturnya.

\begin{tabular}{|c|c|c|c|c|c|c|c|c|c|c|c|c|c|}
\hline 0 & 2 & 1 & 0 & \multirow{4}{*}{+} & 0 & 1 & 0 & 0 & \multirow{4}{*}{$=$} & 0 & 1 & 0 & 0 \\
\hline 1 & 1 & 0 & 1 & & 2 & 1 & 1 & 2 & & 2 & 1 & 1 & 2 \\
\hline 0 & 1 & 0 & 2 & & 1 & 0 & 0 & 1 & & 1 & 0 & 0 & 1 \\
\hline 0 & 2 & 1 & 0 & & 0 & 1 & 2 & 0 & & 0 & 1 & 2 & 0 \\
\hline
\end{tabular}

Gambar 13. Matriks simetris hasil penjumlahan matriks GLCM $4 \times 4$ simetris sudut $0^{\circ}$ dengan transpose-nya

Dari matriks GLCM simetris melewati proses normalisasi, masing-masing nilai pada piksel matriks dibagi dengan jumlah piksel ketetanggaan. Gambar 14 merupakan matrik yang melewati proses normalisasi dengan membagi matriks simetreis dengan jumlah piksel ketetanggaan berjumlah 24 , sehingga masing-masing nilai piksel GLCM tersebut dibagi 24.

\begin{tabular}{|c|c|c|c|}
\hline 0 & $3 / 24$ & $1 / 24$ & 0 \\
\hline $3 / 24$ & $2 / 24$ & $1 / 24$ & $3 / 24$ \\
\hline $1 / 24$ & $1 / 24$ & 0 & $3 / 24$ \\
\hline 0 & $3 / 24$ & $3 / 24$ & 0 \\
\hline
\end{tabular}

Gambar 14. Matriks GLCM $4 \times 4$ Sudut $0^{\circ}$ Setelah Dinormalisasi

Dari normalisasi, nilai ekstraksi ciri pada piksel matriks GLCM $4 \times 4$ dapat diamati melalui tabel 2 sebagai berikut dimana nilai piksel 0 tidak dihitung. 


Tabel 2. Nilai Piksel Matriks GLCM
\begin{tabular}{|c|c|}
\hline Koordinat GLCM & Nilai \\
\hline$(1,2)$ & 0.125 \\
\hline$(1,3)$ & 0.042 \\
\hline$(2,1)$ & 0.125 \\
\hline$(2,2)$ & 0.083 \\
\hline$(2,3)$ & 0.042 \\
\hline$(2,4)$ & 0.125 \\
\hline$(3,1)$ & 0.042 \\
\hline$(3,2)$ & 0.042 \\
\hline$(3,4)$ & 0.125 \\
\hline$(4,2)$ & 0.125 \\
\hline$(4,3)$ & 0.125 \\
\hline
\end{tabular}

Dari nilai piksel matriks GLCM masing-masing koordinat, dihitung nilaini parameter kelima fitur GLCM (kontras, korelasi, energi, IDM dan entropi) sehingga hasilnya sebagaimana disajikan oleh tabel 3.

Tabel 3. Nilai Parameter ekstraksi ciri GLCM 4x4 pada orientasi $0^{\circ}$

\begin{tabular}{|l|c|}
\hline Fitur GLCM & Nilai Parameter \\
\hline Kontras & 0,192 \\
\hline Korelasi & 0,1047 \\
\hline Energi & 0,4418 \\
\hline IDM & 0,1076 \\
\hline entropi & 0.9973 \\
\hline
\end{tabular}

Sedangkan nilai kontras, korelasi, energi dan IDM pada masing-masing citra disajikan oleh tabel 4 berikut ini.

Tabel 4. Parameter data masukan

\begin{tabular}{|l|c|c|c|c|}
\hline \multirow{2}{*}{$\begin{array}{c}\text { Nama } \\
\text { Data }\end{array}$} & \multicolumn{4}{|c|}{ Nilai Parameter GLCM } \\
\cline { 2 - 5 } & Kontras & Korelasi & Energi & IDM \\
\hline Jati_01 & 14616,7 & 0.00585992 & 0,0000146 & 0,311126 \\
\hline Jati_02 & 14634,7 & $-0,0004245$ & 0,0000146 & 0,0312621 \\
\hline Jati_03 & 14770,8 & $-0,0002869$ & 0,0000154 & 0,0306497 \\
\hline Jati_04 & 15766,4 & 0,0036545 & 0,0000149 & 0,0309095 \\
\hline Jati_05 & 14539,8 & 0,0033195 & 0,000015 & 0,0309805 \\
\hline Sengon_01 & 15270,7 & $-0,0017245$ & 0,0000174 & 0,030996 \\
\hline Sengon_02 & 14927 & 0,0022582 & 0,0000171 & 0,0310668 \\
\hline Sengon_03 & 15079,5 & $-0,0002618$ & 0,0000154 & 0,0310239 \\
\hline Sengon_04 & 14371,1 & 0,0102746 & 0,0000184 & 0,0312018 \\
\hline Sengon_05 & 15162,2 & 0,0005629 & 0,0000182 & 0,0313041 \\
\hline Mahoni_01 & 14607,7 & 0,0050828 & 0,0000153 & 0,0311818 \\
\hline Mahoni_02 & 15542,7 & $-0,0031322$ & 0,0000176 & 0,0304796 \\
\hline Mahoni_03 & 15454,5 & 0,0007906 & 0,0000152 & 0,0307979 \\
\hline Mahoni_04 & 14741,6 & $-0,0016068$ & 0,0000158 & 0,0309774 \\
\hline Mahoni_05 & 15402,9 & 0,0016656 & 0,000016 & 0,0308315 \\
\hline Mindi_01 & 15501,1 & 0,0070064 & 0,0000171 & 0,0309018 \\
\hline Mindi_02 & 14980 & $-0,0015536$ & 0,0000151 & 0,0311361 \\
\hline Mindi_03 & 15268,9 & $-0,0022588$ & 0,0000151 & 0,0308615 \\
\hline Mindi_04 & 14614,7 & 0,0029865 & 0,0000153 & 0,0312882 \\
\hline Mindi_05 & 15301,1 & 0,001841 & 0,0000148 & 0,0310061 \\
\hline
\end{tabular}

Dalam penelitian ini, nilai entropy tidak digunakan sebagai masukan dalam proses klasifikasi.

\subsection{MLP}

Metode klasfikasi MLP pada penelitian ini menggunakan hidden layer sebanyak 3 dengan jumlah neuron disetiap hidden layer-nya adalah 20, 30 dan 4 neuron dengan tipe data aktivasi berupa data tansiq, yaitu tipe data yang mempunyai range output dari nilai -1 sampai 1. Dan pada proses MLP peneliti menggunakan nilai biner sebagai vector output pada masing-masing jenis kayu yang sebagai proses labeling data untuk dijadikan data target. Nilai biner vektor output seperti tabel 5 berikut.

Tabel 5. Nilai Biner Vektor Input

\begin{tabular}{|c|c|}
\hline Klasifikasi & Vector Output \\
\hline Kayu jati & {$\left[\begin{array}{llll}1 & 0 & 0 & 0\end{array}\right]$} \\
\hline Kayu sengon & {$\left[\begin{array}{llll}0 & 1 & 0 & 0\end{array}\right]$} \\
\hline Kayu mahoni & {$\left[\begin{array}{llll}0 & 0 & 1 & 0\end{array}\right]$} \\
\hline Kayu mindi & {$\left[\begin{array}{llll}0 & 0 & 0 & 1\end{array}\right]$} \\
\hline
\end{tabular}

Hasil dari klasifikasi MLP diperoleh nilai prediksi yang merupakan hasil dari pengolahan klasifikasi MLP menggunakan 3 hidden layer dan memiliki jumlah neuron 2030 4. Sesuai dengan nilai biner vektor input dari tabel 5 diterapkan proses softmax dan menghasilkan data seperti tabel 6 berikut.

Tabel 6. Hasil Nilai Prediksi

\begin{tabular}{|c|c|c|c|c|c|c|}
\hline \multirow[b]{2}{*}{ 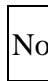 } & \multicolumn{4}{|c|}{ Nilai Prediksi } & \multirow{2}{*}{$\begin{array}{c}\text { Hasil } \\
\text { Softmax }\end{array}$} & \multirow{2}{*}{$\begin{array}{l}\text { Hasil } \\
\text { Output }\end{array}$} \\
\hline & Jati & \begin{tabular}{l|} 
Sengon \\
\end{tabular} & Mahoni & Mindi & & \\
\hline 1 & 0,92123 & 0,02857 & 0,05864 & 0,06822 & 0,92123 & Jati \\
\hline 2 & 0,68187 & 0,21035 & $-0,00010$ & $-0,05818$ & 0,68187 & Jati \\
\hline 3 & 0,97929 & $-0,04637$ & 0,01847 & 0,02498 & 0,97929 & Jati \\
\hline 4 & 0,97589 & 0,04418 & $-0,00826$ & $-0,12474$ & 0,97589 & Jati \\
\hline 5 & 0,95873 & 0,06325 & 0,09188 & 0,07829 & 0,95873 & Jati \\
\hline 6 & 0,05743 & 0,70304 & $-0,13723$ & $-0,16657$ & 0,70304 & Sengon \\
\hline 7 & 0,20126 & 0,55512 & $-0,00465$ & 0,22425 & 0,55512 & Sengon \\
\hline 8 & $-0,09419$ & 0,99602 & 0,01017 & 0,06533 & 0,99602 & Sengon \\
\hline 9 & 0,09152 & 0,99045 & 0,10759 & 0,11056 & 0,99045 & Sengon \\
\hline 10 & $-0,00682$ & 0,99416 & $-0,01379$ & 0,00668 & 0,99416 & Sengon \\
\hline 11 & 0,07238 & $-0,20146$ & 0,94309 & 0,04675 & 0,94309 & Mahoni \\
\hline 12 & $-0,06472$ & $-0,22398$ & 0,97814 & $-0,01594$ & 0,97814 & Mahoni \\
\hline 13 & 0,00290 & 0,05120 & 0,98754 & $-0,00226$ & 0,98754 & Mahoni \\
\hline 14 & $-0,03361$ & 0,10500 & 0,94100 & $-0,00069$ & 0,94100 & Mahoni \\
\hline 15 & $-0,04789$ & $-0,09690$ & 0,98526 & 0,08045 & 0,98526 & Mahoni \\
\hline 16 & $-0,14233$ & $-0,03490$ & $-0,00227$ & 0,89850 & 0,89850 & Mindi \\
\hline 17 & $-0,14233$ & $-0,03490$ & $-0,00227$ & 0,89850 & 0,89850 & Mindi \\
\hline 18 & 0,06401 & $-0,05954$ & 0,00011 & 0,95628 & 0,95628 & Mindi \\
\hline 19 & 0,06401 & $-0,05954$ & 0,00011 & 0,95628 & 0,95628 & Mindi \\
\hline 20 & $-0,12654$ & 0,20452 & 0,00367 & 0,85913 & 0,85913 & Mindi \\
\hline
\end{tabular}


Hasil output berupa data softmax yang didapat dari nilai prediksi. Hasil akhir menghasilkan klasifikasi jenis kayu yang dideteksi berupa jenis kayu.

\subsection{Hasil pengujian}

Penelitian ini menggunakan data uji yang memiliki jumlah data sebanyak 80 data. Dari data uji tersebut per jenis kayu memiliki 20 data uji, dan proporsi data sama dengan data latih, yakni $320 \times 240$ piksel. Dari pengujian didapatkan tabel hasil data uji untuk mencari persentase keberhasian pengujian seperti tabel dibawah ini.

Tabel 7. Persentase Keberhasilan Pengujian

\begin{tabular}{|c|c|c|c|c|c|}
\hline \multirow[t]{2}{*}{ No } & \multirow[t]{2}{*}{ Kategori Percobaan } & \multirow[t]{2}{*}{ Total } & \multicolumn{2}{|c|}{$\begin{array}{c}\text { Hasil } \\
\text { Klasifikasi }\end{array}$} & \multirow{2}{*}{\begin{tabular}{|c|}
$\%$ \\
Keberhasilan \\
Per jenis kayu
\end{tabular}} \\
\hline & & & Benar & Salah & \\
\hline 1. & Kayu Jati & 20 & 19 & 1 & $95 \%$ \\
\hline 2. & Kayu Sengon & 20 & 17 & 3 & $85 \%$ \\
\hline 3. & Kayu Mahoni & 20 & 18 & 2 & $90 \%$ \\
\hline 4. & Kayu Mindi & 20 & 17 & 3 & $85 \%$ \\
\hline & Total Data & 80 & 31 & 9 & - \\
\hline \multicolumn{5}{|c|}{ \% Rata-rata keberhasilan data } & $\mathbf{8 8 , 7 5 \%}$ \\
\hline
\end{tabular}

Dari data persentase keberhasilan pengujian yang disajikan oleh tabel 7 dapat disimpulkan bahwa persentase keberhasilan pada data uji mencapai $88,75 \%$ dari total keseluruhan data sebanyak 80 data dengan rincian percobaan data per jenis kayu 20 data. Semua citra data uji tersebut berukuran $320 \times 240$ piksel.

Analisa dari hasil persentase pada tabel diatas menunjukan bahwa kayu jenis jati dan mahoni menghasilkan nilai persentase diatas rata-rata dikarenakan jenis kayu jati dan mahoni memiliki citra datasheet yang baik dan pada saat proses pemfilteran data train jenis kayu tersebut memiliki nilai tertinggi dalam data target, dimana pada data target pada penelitian adalah $96 \%$ (nilai persentase yang diambil pada data train), akan tetapi pada hasil data validasi persentase nilai akurasi menjadi rata-rata $88,75 \%$, menurun sebesar $7,25 \%$ dikarenakan pada jenis kayu sengon dan mindi memiliki nilai persentase dibawah rata-rata dengan hasil sebesar $85 \%$ yang dimungkinkan pada citra data kayu tersebut memiliki nilai parameter yang hampir sama jadi pada klasifikasi lebih cenderung diklasifikasi jenis kayu yang berbeda.

Dari pengujian ini menghasilkan tingkat akurasi dari penerapan metode GLCM dengan preprosessing (konversi citra RGB ke grayscale dan penajaman citra tekstur) kemudian diklasifikasi dengan menggunakan metode MLP mendapatkan nilai keberhasilan data sebesar $88,75 \%$.

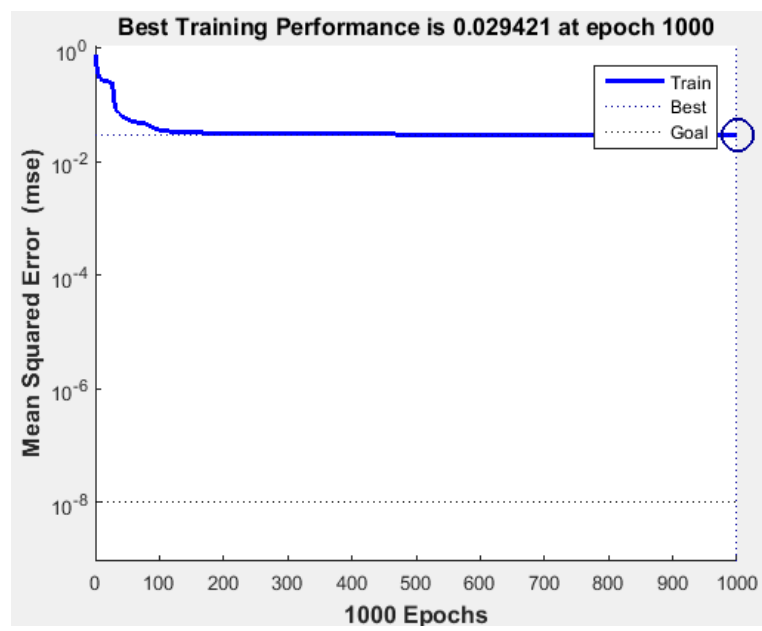

Gambar 12. Hasil performa data training

Pada gambar 12 diatas merupakan hasil MSE dari data training yang diproses dengan metode MLP, dengan hasil terbaik dari kinerja data training untuk dapat mengklasifikasikan dari 4 jenis kayu tersebut dari performa terbaik (jaringan nilai error yang paling mendekati target) sebesar 0.029421 dengan epoch sebesar 1.000 .

\section{Kesimpulan}

Proses ekstraksi fitur menggunakan metode GLCM pada masing-masing citra kayu jati, sengon, mahoni dan mindi dengan penajaman citra pada nilai radius 10 dan amount 2 dapat menghasilkan nilai parameter GLCM berupa correlation, contrast, energy dan homogeneity yang bervariasi.

Penerapan metode MLP untuk klasifikasi citra kayu jati, sengon, mahoni dan mindi pada penelitian ini dapat berjalan dengan baik dengan jumlah neuron sebanyak 20, 30 dan 4 neuron pada hidden layer dan menghasilkan akurasi sistem pada data train sebesar $96 \%$. Pada saat pengujian data validasi, tingkat akurasi menurun sebesar 7,25\%.

\section{Daftar Pustaka}

[1] I. Santoso, Y. Christyono, and M. Indriani, "Kinerja Pengenalan Citra Tekstur menggunakan Analisis Tekstur Metode Run Length," in Seminar Nasional Aplikasi Teknologi Informasi (SNATI), 2007.

[2] I. Gunawan, J. Halomoan, and R. D. Atmaja, "Perancangan Sistem Identifikasi Kualitas Kayu Untuk Quality Kontrol Berbasis Pengolahan Citra Digital," eProceedings Eng., 
vol. 2, no. 1, 2015.

[3] A. Fahrurozi, S. Madenda, D. Kerami, and others, "Wood texture features extraction by using GLCM combined with various edge detection methods," in Journal of Physics: Conference Series, 2016, vol. 725, no. 1, p. 12005.

[4] M. I. Fathurrahman, J. Jondri, and A. A. Rohmawati, "Sistem Klasifikasi Kualitas Kayu Jati Berdasarkan Jenis Tekstur Dengan Jaringan Syaraf Tiruan Menggunakan Graylevel-co-occurence Matrix," eProceedings Eng., vol. 6, no. 2, 2019.

[5] A. W. Sanjaya, "Deteksi Penyakit Kulit Menggunakan Analisis Fitur Warna dan Tekstur Dengan Metode Color Moment, Gray Level Cooccurence Matrix dan Jaringan Saraf Tiruan Backpropagation," Inst. Teknol. Telkom, 2011.

[6] J. F. Dumanauw, Mengenal Kayu <EDISI $B A R U>$. Kanisius.

[7] R. A. Pramunendar, D. P. Prabowo, D. Pergiwati, and K. Latifa, "KLASIFIKASI JENIS KAYU MENGGUNAKAN BACKPROPAGATION NEURAL NETWORK BERDASARKAN FITUR GRAY LEVEL COOCCURRENCE MATRIX," Sens 3, vol. 1, no. 1, 2017.

[8] D. Putra, Pengolahan citra digital. Penerbit Andi, 2010.

[9] M. A. Afandi, S. I. Purnama, and R. F. Crisianti, "Implementasi Metode Deteksi Tepi Laplacian dan Jarak Euclidean untuk Identifikasi Tanda Tangan," J. Nas. Tek. Elektro, vol. 9, no. 1, pp. 34-43, 2020.

[10] S. Santosa, M. Martono, M. B. Utomo, and B. S. Budi, "Seleksi Arah Sudut Komputasi Dan Fitur Glcm Pada Kstraksi Citra Kayu Jati, Mahoni, Mindi, Dan Sengon," Wahana Tek. Sipil J. Pengemb. Tek. Sipil, vol. 23, no. 2, pp. 77-87, 2019.

[11] K. Lloyd, P. L. Rosin, D. Marshall, and S. C. Moore, "Detecting violent and abnormal crowd activity using temporal analysis of grey level co-occurrence matrix (GLCM)-based texture measures," Mach. Vis. Appl., vol. 28, no. 3-4, pp. 361-371, 2017.

[12] O. R. Indriani, E. J. Kusuma, C. A. Sari, E. H. Rachmawanto, and others, "Tomatoes classification using K-NN based on GLCM and HSV color space," in 2017 international conference on innovative and creative information technology (ICITech), 2017, pp.
$1-6$.

[13] S. Han, J. Pool, J. Tran, and W. Dally, "Learning both weights and connections for efficient neural network," in Advances in neural information processing systems, 2015, pp. 1135-1143.

[14] N. Purwaningsih, "Penerapan Multilayer Perceptron Untuk Klasifikasi Jenis Kulit Sapi Tersamak," J. TeknoIf, vol. 4, no. 1, 2016.

[15] K. Kwon, D. Kim, and H. Park, "A parallel MR imaging method using multilayer perceptron," Med. Phys., vol. 44, no. 12, pp. 6209-6224, 2017. 